\title{
Investigating the surface performance of impregnated and varnished Calabrian pine wood against weathering
}

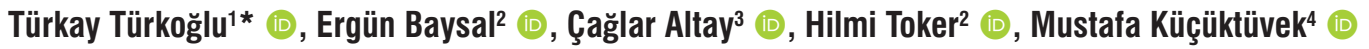 \\ and Ahmet Gündüz ${ }^{2}$ \\ 'Department of Forestry, Koycegiz Vocational School, Muğla Sıtkı Koçman University, Muğla, Turkey \\ 2Department of Wood Science and Technology, Faculty of Technology, Muğla Sıtkı Koçman University, \\ Muğla, Turkey \\ ${ }^{3}$ Department of Furniture and Decoration, Aydin Vocational School, Aydin Adnan Menderes University, \\ Aydın, Turkey \\ ${ }^{4}$ Department of Interior Architecture and Environmental Design, Fine Arts and Architecture Faculty, \\ Antalya Bilim University, Antalya, Turkey \\ *turkayturkoglu@mu.edu.tr
}

\begin{abstract}
The study investigates the gloss and color changes values of Calabrian pine (Pinus brutia Ten.) wood impregnated with some copper content impregnation chemicals such as Celcure C4, Korasit KS, and Tanalith E 8000 and then waterbased varnish (WBV) and polyurethane varnish (PV) coated after 6 months of weathering. The results of study showed that gloss values of PV coated Calabrian pine wood were higher than that of WBV coated Calabrian pine wood before weathering. The gloss values of all treatment groups decreased after weathering. Lightness values of Calabrian pine wood also decreased for all treatment groups after weathering. Pre-impregnation before PV coating resulted in lower $\Delta L^{*}$ values of Calabrian pine wood. While all treatment groups tended to turn reddish by giving $\Delta a^{*}$ positive values, they tended to turn bluish by giving negative $\Delta b^{*}$ values. The lowest total color change was obtained with only WBV coated Calabrian pine wood.
\end{abstract}

Keywords: impregnation, weathering, varnish, color and gloss test, Calabrian pine wood.

How to cite: Türkoğlu, T., Baysal, E., Altay, Ç., Toker, H., Küçüktüvek, M., \& Gündüz, A. (2020). Investigating the surface performance of impregnated and varnished Calabrian pine wood against weathering. Polímeros: Ciência e Tecnologia, 30(4), e2020045. https://doi.org/10.1590/0104-1428.10120

\section{Introduction}

Wood is an environmentally friendly and sustainable natural material used for a wide variety of both structural and non-structural applications ${ }^{[1,2]}$, especially in building and construction applications ${ }^{[3]}$. In addition to many positive properties of wood material, there are some undesirable negative properties. The wood material can be burned, absorb water, exposed to fungal and insect attack, unprotected against outside weathering factors. Environmental conditions such as atmospheric pollutants, oxygen, moisture, sunlight, cold, heat, chemicals, and wind erosion can cause an economic depreciation by reduced service life of wood. Therefore, it is necessary to protect the wood material in certain ways in order to protect it against such weather conditions. The coating is applied to protect wooden surfaces from environmental influences, biological degradation, and corrosion ${ }^{[4]}$. Coating adds an aesthetic appearance to wooden surfaces, making it desirable for the users $^{[5]}$. However, coating thickness becomes thinner over time. The tissues on the surface undergo deformation ${ }^{[6]}$. Wood should be impregnated with suitable material and varnish applied before it is used in structural or furniture production. After these processes, the wood used outdoors is much more durable in terms of biological decomposition, dimensional changes and photochemical degradation ${ }^{[7]}$. Thus, modification techniques with impregnating agents can increase the resistance of wood to weather conditions ${ }^{[8]}$. One of the methods applied for the protection of outdoor degradation of wood material is impregnation with watersoluble salts such as chromium and copper. The use of various impregnating agents has become important in place of chromated copper arsenate (CCA) impregnation, which is a water-soluble impregnation agent and has been used in large quantities throughout the world. Most of them do not contain arsenic and can be listed as follows: Acid copper chromium (ACC); alkali copper quat (ACQ); copper azole (CA); copper citrate (CC); copper diethyldithiocarbamate (CDDC); copper $\mathrm{HDO}^{[9]}$. Since the carcinogenic structure of chromium compounds is well known, the new impregnation agent is generally seen as copper in alternative substances ${ }^{[10]}$. Zhang et al. ${ }^{[1]]}$ in their study, found that by impregnating with copper ethanolamine after the accelerated weather conditions test, they greatly prevented the change in the 
surface properties of the wood materials. Altay et al. ${ }^{[12]}$ investigated color changes of Scots pine wood impregnated with copper content chemical before synthetic, cellulosic, polyurethane varnishes (PV) coating after weathering. They found that a good color stability in the Scots pine specimens treated with Wolmanit CX-8 (WCX-8) before PV coated of weathering conditions.

This study was presented at Calabrian pine (Pinus brutia Ten.) wood impregnated with a 2.5 and 5 percent aqueous solutions of copper-based chemicals such as Celcure C4, Korasit KS, and Tanalith E 8000. After impregnation, waterbased varnish (WBV) and PV were coated to the wood surface. After the preparation process the wood specimens were exposed to the weather condition for 6 months in Mugla Province of Turkey. Therefore, this study aims at investigating the effect of weathering on gloss and color changes of impregnated Calabrian pine wood with copper content impregnation chemicals before water-based and polyurethane varnishes coatings.

\section{Materials and Methods}

\subsection{Preparation of wood specimens}

The Calabrian pine (Pinus brutia Ten.) wood specimens were used with a dimension of $10 \mathrm{~mm}$ x $100 \mathrm{~mm}$ x $150 \mathrm{~mm}$ (radial $\mathrm{x}$ tangent $\mathrm{x}$ longitudinal). The test samples were conditioned for two weeks at $20{ }^{\circ} \mathrm{C}$ and $65 \%$ relative humidity before testing.

\subsection{Impregnation process}

The Calabrian pine wood specimens were impregnated with $2.5 \%$ and $5 \%$ aqueous solutions of impregnation chemicals according to ASTM D1413-07e $1^{[13]}$. The retention values of the test samples at the end of the impregnation were calculated by the following formula 1 :

$$
\text { Retention }=\frac{G \cdot C}{V} X 10^{3}\left(\mathrm{Kg} / \mathrm{m}^{3}\right)
$$

$\mathrm{G}=\mathrm{T}_{2}-\mathrm{T}_{1}$

$\mathrm{T}_{1}$ : Weight of specimen before impregnation $(\mathrm{g})$

$\mathrm{T}_{2}$ : Weight of specimen after impregnation $(\mathrm{g})$

$\mathrm{V}$ : Volume of specimen volume $\left(\mathrm{cm}^{3}\right)$

$\mathrm{C}$ : Concentration (\%)

\subsection{Application of varnish}

The Calabrian pine wood specimens were varnished with polyurethane and water-based varnishes after the impregnation process in this study. Polyurethane varnish application; all surfaces and edges of specimens were applied polyurethane varnish with a spray gun according to ASTM D3023-98 standard ${ }^{[14]}$. Before the application of polyurethane varnish, the surfaces were cleaned from dust by the suitable sanding process. After the polyurethane varnish was mixed thoroughly, it was thinned by the addition of thinner, and two cross-layers were applied on normal porous surfaces. Then, the wood specimens were sanded with sand number 220 and the topcoat application started. In water-based varnish application, after sanding the wooden surfaces with 220 grit sandpaper, the varnish was taken to an empty container and coated to all surfaces and edges of the wood with a brush. During the application, the undiluted varnish was applied in 2 layers. Polyurethane and water-based varnish application values are as follows:

Polyurethane varnish: Filling: $100 \mathrm{~g} / \mathrm{m}^{2}$ - Topcoat: $100 \mathrm{~g} / \mathrm{m}^{2}$

Water-based varnish: Filling: $100 \mathrm{~g} / \mathrm{m}^{2}$ - Topcoat: $100 \mathrm{~g} / \mathrm{m}^{2}$

\subsection{Gloss test}

The gloss values Calabrian pine wood specimens were determined using a gloss meter (BYK Gardner, MicroTRIGloss) according to ASTM D523-14 ${ }^{[15]}$. The measurement geometry was chosen a $60^{\circ}$ incidence angle. Ten replicates were made for each treatment group. Gloss measurements were made parallel to the fibers.

\subsection{Color test}

The color parameters $a^{*}, b^{*}$ and $L^{*}$ were determined by the CIEL*a*b* method (Figure 1).

The $L^{*}$ axis shows brightness, while $a^{*}$ and $b^{*}$ are color coordinates. The parameters $+a^{*}$ and $-a^{*}$ show red and green, respectively. The parameter $+b^{*}$ shows yellow, while $-b^{*}$ shows. $L^{*}$ can range from 100 (white) to 0 (black). The total color changes $\left(\Delta E^{*}\right)$ for Calabrian pine wood specimens were determined by ASTM D 1536-58 $\mathrm{T}^{[16]}$. Equations 2-5:

$$
\begin{aligned}
& \Delta a^{*}=a f^{*}-a i^{*} \\
& \Delta b^{*}=b f^{*}-b i^{*} \\
& \Delta L^{*}=L f^{*}-L i^{*} \\
& \left(\Delta E^{*}\right)=\left(\left(\Delta a^{*}\right)^{2}+\left(\Delta b^{*}\right)^{2}+\left(\Delta L^{*}\right)^{2}\right.
\end{aligned}
$$

Where: $\Delta a^{*}, \Delta b^{*}$, and $\Delta L^{*}$ are the changes between the first and last range values. Ten replicates were made for each treatment group. Color measurements were made parallel to the fibers.

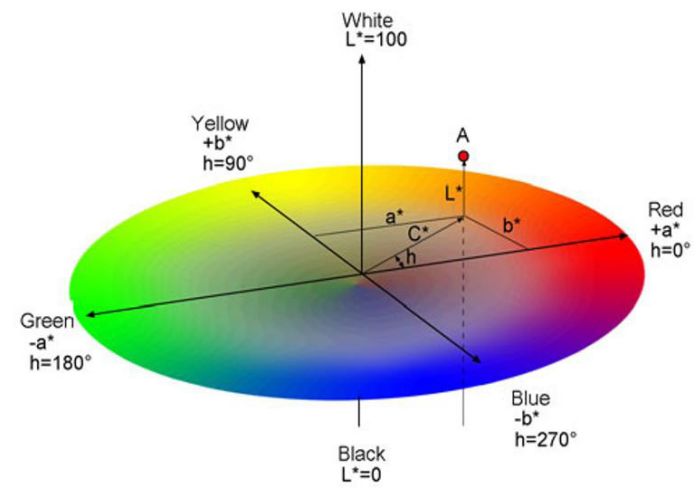

Figure 1. The CIEL*a*b* colour space ${ }^{[6]}$. 


\subsection{Weathering test}

The Calabrian pine wood was exposed to weathering for 6 months from May to November in 2019. The wood panels were prepared for weathering according to ASTM D $358-55^{[17]}$. A test site has been established for practical evaluations near Muğla Regional Meteorological Observation Station in the South Aegean Region. The meteorological data of Muğla is provided in Table 1 .

\subsection{Statistical evaluations}

IBM SPSS $^{\circledR}$ program was used to evaluate the test results. Variance Analysis and Duncan tests were performed on the results. The Variance Analysis and Duncan test applied at 95\% confidence level in these test result. Statistical evaluations were made on homogeneity groups (HG) where different letters reflect statistical significance according to test results. Ten replicates were made for each treatment group and total 140 data were analysed.

\section{Results and Discussions}

\subsection{Gloss test results}

The gloss and gloss losses values of impregnated and varnished Calabrian pine wood before and after weathering are demonstrated in Table 2. A clear coating application is the easiest and most common method to protect wood against weather conditions and increase its distinctive appearance.
Varnished wood samples reflect the natural appearance of wood surfaces ${ }^{[18]}$.

In this study, while the highest gloss value (99.52) was obtained with PV coated Calabrian pine wood, the lowest gloss value (44.56) was obtained with 5\% Korasit KS+WBV treated Calabrian pine wood before weathering. Baysal et al. ${ }^{[18]}$ found that that the glossiness of Scots pine impregnated with some copper content chemical before polyurethane varnish coating ranged from 96 to 103 depending on the treatment. Another study, Toker et al. ${ }^{[19]}$ reported that the gloss values of Calabrian pine pre-treated with borates before polyurethane varnish coating ranged from 89.1 to 97 . Our results were similar to Baysal et al. ${ }^{[18]}$ and Toker et al. ${ }^{[19]}$. Except for the Korasit KS+WBV and Tanalith E $8000+$ WBV treatment groups at all concentrations, the glosses of the Calabrian pine wood increased with rising concentration levels of chemicals. Pre-impregnation with chemicals before the PV coating decreased the gloss values of Calabrian pine wood. The chemicals can limit gloss to a certain degree in test samples before weathering. The reason for the experimental results reached may be due to the dispersion and absorption of rays reflected from salt crystals. There are photoactive ions on the wood surface. Varnished wood due to photoactive ions may loss of gloss before decomposition ${ }^{[7]}$. These results are similar to the gloss values of Scots pine and Oriental beech wood impregnated before varnishing ${ }^{[20,21]}$. Gündüz et al. ${ }^{[22]}$ investigated gloss values of Scots pine pre-impregnated with some copper-based chemicals such as Wolmanit CX-8 and Celcure AC 500 before water-based varnish coating. They found that pre-impregnation with chemicals before

Table 1. Meteorological data of Muğla.

\begin{tabular}{|c|c|c|c|c|c|c|}
\hline Months & May & June & July & August & September & October \\
\hline Average temperature per month $\left({ }^{\circ} \mathrm{C}\right)$ & 18.4 & 23.4 & 26.1 & 27.8 & 22.6 & 18.0 \\
\hline Humidity per month $(\%)$ & 54.4 & 55.4 & 42.7 & 40.0 & 53.3 & 65.1 \\
\hline Average wind speed per month $(\mathrm{m} / \mathrm{sn})$ & 1.3 & 1.4 & 1.8 & 1.7 & 1.4 & 0.9 \\
\hline Total rainfall per month $\left(\mathrm{mm}=\mathrm{kg} / \mathrm{m}^{-2}\right)$ & 9. 0 & 76.5 & 43.2 & 16.4 & 51.4 & 78.6 \\
\hline Number of rainy days & 5 & 12 & 1 & 1 & 5 & 5 \\
\hline
\end{tabular}

Table 2. Gloss change values of Calabrian pine wood specimens before and after natural weathering.

\begin{tabular}{|c|c|c|c|c|c|c|c|c|}
\hline \multirow[t]{2}{*}{ Impregnation + Varnish } & \multirow[t]{2}{*}{$\begin{array}{c}\text { Concentration } \\
(\%)\end{array}$} & \multirow[t]{2}{*}{$\begin{array}{c}\text { Retention } \\
\left(\mathbf{K g} / \mathbf{m}^{3}\right)\end{array}$} & \multicolumn{2}{|c|}{$\begin{array}{c}\begin{array}{c}\text { Before natural } \\
\text { weathering }\end{array} \\
\text { gloss values } \\
\end{array}$} & \multicolumn{2}{|c|}{$\begin{array}{c}\begin{array}{c}\text { After } 6 \text { months of } \\
\text { natural weathering }\end{array} \\
\text { gloss values } \\
\end{array}$} & \multicolumn{2}{|c|}{ Gloss losses (\%) } \\
\hline & & & Mean & SD & Mean & SD & Mean & HG \\
\hline PV & - & - & 99.52 & 9.72 & 55.32 & 5.95 & -44.41 & $\mathrm{C}$ \\
\hline WBV & - & - & 46.26 & 6.50 & 24.15 & 3.25 & -47.79 & $\mathrm{DE}$ \\
\hline Celcure C4+PV & 2.5 & 13.48 & 97.60 & 11.19 & 57.24 & 6.10 & -41.35 & $\mathrm{~B}$ \\
\hline Celcure C4+PV & 5.0 & 30.92 & 98.36 & 10.06 & 43.30 & 9.58 & -55.97 & $\mathrm{G}$ \\
\hline Korasit KS+ PV & 2.5 & 14.88 & 97.93 & 9.76 & 56.25 & 7.03 & -42.56 & $\mathrm{~B}$ \\
\hline Korasit KS+ PV & 5.0 & 32.11 & 98.66 & 8.87 & 50.90 & 8.55 & -48.40 & $\mathrm{E}$ \\
\hline Tanalith E $8000+\mathrm{PV}$ & 2.5 & 15.05 & 93.12 & 12.49 & 54.57 & 6.45 & -41.39 & $\mathrm{~B}$ \\
\hline Tanalith E $8000+\mathrm{PV}$ & 5.0 & 31.47 & 96.36 & 13.11 & 51.66 & 7.48 & -46.38 & $\mathrm{D}$ \\
\hline Celcure C4+ WBV & 2.5 & 13.48 & 50.43 & 6.89 & 19.79 & 5.69 & -60.75 & $\mathrm{H}$ \\
\hline Celcure C4+ WBV & 5.0 & 30.92 & 54.68 & 8.05 & 33.94 & 5.04 & -37.92 & $\mathrm{~A}$ \\
\hline Korasit KS+ WBV & 2.5 & 14.88 & 52.90 & 12.61 & 24.62 & 5.84 & -53.45 & $\mathrm{~F}$ \\
\hline Korasit KS+ WBV & 5.0 & 32.11 & 44.56 & 6.39 & 22.90 & 5.69 & -48.60 & $\mathrm{E}$ \\
\hline Tanalith E $8000+$ WBV & 2.5 & 15.05 & 52.62 & 7.90 & 22.46 & 4.26 & -57.31 & $\mathrm{G}$ \\
\hline Tanalith E $8000+$ WBV & 5.0 & 31.47 & 52.62 & 5.72 & 32.15 & 5.89 & -38.91 & A \\
\hline
\end{tabular}

Note: Results reflect the average of 10 Calabrian pine wood specimens. PV: Polyurethane varnish; WBV: Water-based varnish; SD: Standard deviation; HG: Homogeneity groups; A-G letters: Statistical differences. 
WBV coating caused increase in the gloss of Scots pine. In addition, Gündüz et al. ${ }^{[23]}$ studied gloss values of Scots pine pre-impregnated with some copper-containing chemicals before polyurethane varnish (PV) coating. They reported that pre-impregnation with chemicals before $\mathrm{PV}$ coating caused decrease in the gloss of Scots pine. In our study, after the weathering process, the glosses of all Calabrian pine wood decreased. Because erosion and abrasion on the wood surfaces cause gloss loss in the varnish layers after weathering ${ }^{[7,24]}$. Gloss losses values after 6 months of weathering range from $-37.92 \%$ to $-60.75 \%$. Türkoglu et al. ${ }^{[20]}$ found that gloss loss of some copper-based chemicals treated and polyurethane varnish coated Scots pine ranged from $59.91 \%$ to $69.90 \%$ after 6 months of weathering. Surprisingly, our results showed that lower concentration levels (2.5\%) of chemicals for PV coated Calabrian pine wood caused decrease in gloss losses of Calabrian pine wood samples after weathering. For WBV coated Calabrian pine wood, higher concentration levels of chemicals resulted in lower gloss losses of Calabrian pine wood after weathering.

\subsection{Color test results}

The color parameters, color changes, and total color change values of the Calabrian pine wood impregnated with copper content chemicals and varnished before and after weathering are given in Table 3. According to Table 3, while the highest $L^{*}$ value (70.89) was obtained with WBV coated Calabrian pine wood, the lowest $L^{*}$ value (43.13) was measured with 5\% Tanalith E $8000+\mathrm{PV}$ treated Calabrian pine wood before weathering. Our results showed that pre-impregnation with copper-based chemicals before varnishing caused decrease $L^{*}$ values of Calabrian pine wood to some extent.
Baysal ${ }^{[25]}$ investigated the color characteristics of Scots pine wood impregnated with some copper content chemicals before polyurethane varnish coating after accelerated weathering. They reported that pre-impregnation with chemicals before varnish coating reduced $L^{*}$ values of Scots pine wood before accelerated weathering. The results of our study are in good agreement with data Baysal ${ }^{[25]}$. Gündüz et al. ${ }^{[22]}$ studied color characteristics of Wolmanit CX-8, Adolit KD-5 and Celcure AC 500 impregnated Scots pine wood before water-based varnish (WBV) coating after accelerated weathering. They reported that $L^{*}$ values of Scots pine wood decreased impregnated with chemicals before WBV coating before weathering. The results are in good agreement with Gündüz et al. ${ }^{[22]}$. Concentration levels of chemicals had no significant effect on the $L^{*}$ values of Calabrian pine wood before weathering. While $a^{*}$ values range from 0.87 to 6.32 , $b^{*}$ values vary between 30.34 to 42.29 before weathering. After 6 months of weathering, the $\Delta L^{*}$ values of Calabrian pine wood decreased for all treatment groups. Since wood surfaces are delicate to UV light, the $\Delta L^{*}$ values were negative in all treatments. Chemical changes ensue in wood constituent such as lignin on surfaces of wood during photo degradation ${ }^{[26]}$. Depolymerisation of lignin may cause the darkening of the wood surface ${ }^{[18,27,28]}$. Pre-impregnation with chemicals before PV coating gave lower $\Delta L^{*}$ values than only PV coated Calabrian pine wood. Because $\Delta L^{*}$ value was -7.75 for only PV coated Calabrian pine wood, it changed from -0.29 to -6.65 for impregnated and PV coated Calabrian pine wood. $\Delta L^{*}$ values of Calabrian pine wood increased with increasing concentration levels of chemicals. All treatment groups tended to turn reddish and bluish, giving a positive $\Delta a^{*}$ and negative $\Delta b^{*}$ values, respectively after natural weathering. Ghosh et al. ${ }^{[28]}$ studied color characteristics of a copper-containing chemical such

Table 3. Color change values of the Calabrian pine wood specimens before and after natural weathering.

\begin{tabular}{|c|c|c|c|c|c|c|c|c|c|c|c|c|c|c|c|}
\hline \multirow[t]{3}{*}{$\begin{array}{l}\text { Impregnation + } \\
\text { Varnish }\end{array}$} & \multirow[t]{3}{*}{$\begin{array}{l}\text { Conc. } \\
(\%)\end{array}$} & \multirow{2}{*}{\multicolumn{3}{|c|}{$\begin{array}{l}\text { Color values before } \\
\text { natural weathering }\end{array}$}} & \multirow{2}{*}{\multicolumn{3}{|c|}{$\begin{array}{c}\text { Color change } \\
\text { values after natural } \\
\text { weathering }\end{array}$}} & \multirow{2}{*}{\multicolumn{2}{|c|}{$\Delta L^{*}$}} & \multirow{2}{*}{\multicolumn{2}{|c|}{$\Delta a^{*}$}} & \multirow{2}{*}{\multicolumn{2}{|c|}{$\Delta b^{*}$}} & \multirow{2}{*}{\multicolumn{2}{|c|}{$\begin{array}{c}\begin{array}{c}\text { Total color } \\
\text { change }\end{array} \\
\text { values after } \\
\begin{array}{c}\text { natural } \\
\text { weathering }\end{array} \\
\Delta \mathrm{E}^{*} \\
\end{array}$}} \\
\hline & & & & & & & & & & & & & & & \\
\hline & & $L i^{*}$ & $a i^{*}$ & $\overline{b i^{*}}$ & $L f^{*}$ & $a f^{*}$ & $\overline{b f^{*}}$ & Mean & HG & Mean & $\overline{\text { HG }}$ & Mean & HG & Mean & HG \\
\hline $\mathrm{PV}$ & - & 67.92 & 6.32 & 41.51 & 60.17 & 14.18 & 37.10 & -7.75 & G & 7.86 & $\mathrm{ABC}$ & -4.41 & A & 11.88 & $\mathrm{DE}$ \\
\hline WBV & - & 70.89 & 4.79 & 33.03 & 66.00 & 11.01 & 30.84 & -4.89 & $\mathrm{DE}$ & 6.22 & $\mathrm{DE}$ & -2.19 & A & 8.20 & $\mathrm{G}$ \\
\hline Celcure C4+PV & 2.5 & 49.78 & 4.15 & 42.29 & 44.36 & 12.15 & 23.51 & -5.42 & $\mathrm{E}$ & 8.00 & $\mathrm{ABC}$ & -18.78 & $\mathrm{EF}$ & 21.12 & $\mathrm{AB}$ \\
\hline Celcure C4+PV & 5.0 & 44.47 & 1.24 & 30.34 & 40.79 & 8.45 & 25.83 & -3.68 & $\mathrm{C}$ & 7.21 & $\mathrm{BCD}$ & -4.51 & A & 9.26 & $\mathrm{G}$ \\
\hline Korasit KS+ PV & 2.5 & 50.36 & 3.82 & 40.50 & 43.71 & 12.32 & 23.17 & -6.65 & $\mathrm{~F}$ & 8.50 & $\mathrm{AB}$ & -17.33 & E & 20.41 & B \\
\hline Korasit KS+ PV & 5.0 & 46.90 & 2.09 & 33.53 & 43.36 & 8.55 & 23.59 & -3.54 & $\mathrm{C}$ & 6.46 & $\mathrm{DE}$ & -9.94 & $\mathrm{C}$ & 12.37 & $\mathrm{DE}$ \\
\hline Tanalith E $8000+\mathrm{PV}$ & 2.5 & 50.46 & 3.04 & 39.34 & 50.17 & 11.95 & 29.22 & -0.29 & A & 8.91 & A & -10.12 & $\mathrm{C}$ & 13.48 & $\mathrm{D}$ \\
\hline Tanalith E $8000+\mathrm{PV}$ & 5.0 & 43.13 & 3.07 & 37.93 & 42.67 & 9.49 & 16.51 & -0.46 & A & 6.42 & $\mathrm{DE}$ & -21.42 & G & 22.36 & A \\
\hline Celcure C4+ WBV & 2.5 & 49.57 & 2.07 & 33.74 & 49.32 & 10.24 & 26.27 & -0.25 & A & 8.17 & $\mathrm{ABC}$ & -7.47 & B & 11.07 & $\mathrm{EF}$ \\
\hline Celcure C4+ WBV & 5.0 & 44.01 & 2.00 & 31.34 & 39.64 & 9.04 & 17.17 & -4.37 & $\mathrm{CD}$ & 7.04 & $\mathrm{CD}$ & -14.17 & $\mathrm{D}$ & 16.41 & $\mathrm{C}$ \\
\hline Korasit KS+ WBV & 2.5 & 56.12 & 3.59 & 39.60 & 46.75 & 9.46 & 19.80 & -9.37 & $\mathrm{H}$ & 5.87 & $\mathrm{DE}$ & -19.80 & FG & 22.67 & A \\
\hline Korasit KS+ WBV & 5.0 & 49.99 & 2.18 & 33.07 & 48.40 & 9.44 & 24.41 & -1.59 & $\mathrm{~B}$ & 7.26 & $\mathrm{BCD}$ & -8.66 & $\mathrm{BC}$ & 11.41 & $\mathrm{EF}$ \\
\hline Tanalith E 8000 + WBV & 2.5 & 51.01 & 3.30 & 38.80 & 44.21 & 8.86 & 17.86 & -6.80 & $\mathrm{~F}$ & 5.56 & $\mathrm{E}$ & -20.94 & FG & 22.70 & A \\
\hline Tanalith E $8000+$ WBV & 5.0 & 52.35 & 0.87 & 30.56 & 48.53 & 8.97 & 26.63 & -3.82 & $\mathrm{C}$ & 8.10 & $\mathrm{ABC}$ & -3.93 & A & 9.77 & FG \\
\hline
\end{tabular}

Note: Results reflect the average of 10 Calabrian pine wood specimens. PV: Polyurethane varnish; WBV: Water-based varnish; Conc: Concentration (\%); HG: Homogeneity groups; A-G letters: Statistical differences 
as Wolmanit CX-8 impregnated and PV coated Oriental beech after $500 \mathrm{~h}$ of Scots pine specimens after accelerated weathering. They revealed that Scots pine specimens showed reddish, giving a positive $\Delta a^{*}$ values and gave negative $\boldsymbol{\Delta} b^{*}$ values tended to turn bluish. Türkoğlu et al. ${ }^{[20]}$ studied color changes of a copper-based chemical such as Adolit KD 5 impregnated and PV coated Oriental beech wood samples. They explained that Oriental beech wood gave negative $\Delta a^{*}$ and $\Delta b^{*}$ values, respectively after 6 months of weathering. In this study, while the highest total color change $\left(\Delta E^{*}\right)$ was obtained in $2.5 \%$ Tanalith $\mathrm{E}$ $8000+$ WBV treated Calabrian pine wood, the lowest total color change was determined in the only WBV coated wood specimens. The total color changes of Calabrian pine wood vary between 8.20 to 22.70 after weathering. In this study, as the concentration levels of chemicals increased, total color change of Calabrian pine wood decreased. In other words, the increase in concentration levels of chemicals has produced positive results in terms of total color changes of Calabrian pine wood. Yalinkilic et al. ${ }^{[7]}$ investigated the weathering performance of Scots pine and chestnut wood impregnated with chromium-copper-boron (CCB) before polyurethane varnish coating. They reported that CCB impregnation reduced total color changes of Scots pine and chestnut wood. Türkoğlu et al. ${ }^{[20]}$ reported that impregnation of wood some copper content chemicals before polyurethane varnish coating reduced total color changes of wood after weathering. Gündüz et al ${ }^{[22]}$ found that preimpregnation with copper-based chemicals such as Adolit KD 5, Wolmanit CX-8, and CAC 500 before water-based varnish coating reduced total color changes of Scots pine after $1000 \mathrm{~h}$ of accelerated weathering. Our results are similar to Yalinkilic et al. ${ }^{[7]}$, Türkoğlu et al. ${ }^{[20]}$, and Gündüz et al. ${ }^{[22]}$.

\section{Conclusions}

The gloss losses were observed for all treatment groups after weathering. The gloss values of PV coated Calabrian pine wood were higher than that of SBW coated Calabrian pine wood before weathering. While higher concentration levels for WBV coated Calabrian pine wood resulted in lower gloss losses, higher concentration levels of PV coated Calabrian pine wood resulted in higher gloss losses after weathering. $\Delta L *$ values of impregnated and coated Calabrian pine wood decreased. All treatment groups giving positive $\Delta a^{*}$ and negative $\Delta b^{*}$ values tended to turn reddish and bluish, respectively after weathering. Total color change $\left(\Delta E^{*}\right)$ was the lowest for only WBV coated Calabrian pine wood. Additionally, higher concentration levels of chemicals resulted in lower total color changes of Calabrian pine wood after weathering.

\section{Acknowledgements}

This study has been granted by the Muğla Sttkı Koçman University Research Projects Coordination Office through Project Grant Number (18/024).

\section{References}

1. Priadi, T., \& Hiziroglu, S. (2013). Characterization of heat Treated wood species. Materials \& Design, 49, 575-582. http:// dx.doi.org/10.1016/j.matdes.2012.12.067.
2. Obata, Y., Takeuchi, K., Furuta, Y., \& Kanayama, K. (2005). Research on better use of wood for sustainable development: quantitative evaluation of good tactile warmth of wood. Energy, 30(8), 1317-1328. http://dx.doi.org/10.1016/j.energy.2004.02.001.

3. Woodard, A. C., \& Milner, H. R. (2016). Sustainability of construction materials. United Kingdom: Woodhead Publishing.

4. Akbarian, M., Olya, M. E., Ataeefard, M., \& Mahdavian, M. (2012). The Influence of NaNosilver on thermal and antibacterial properties of A $2 \mathrm{~K}$ waterborne polyurethane coating. Progress in Organic Coatings, 75(4), 344-348. http:// dx.doi.org/10.1016/j.porgcoat.2012.07.017.

5. De Meijer, M. (2001). Review on the durability of exterior wood coatings with reduced VOC-content. Progress in Organic Coatings, 43(4), 217-225. http://dx.doi.org/10.1016/S03009440(01)00170-9.

6. Hunt, R. (1995). Measuring color. United Kingdom: Ellis Horwood Limited.

7. Yalinkilic, M. K., Ilhan, R., Imamura, Y., Takahashi, M., Demirci, Z., Yalınkilic, A. C., \& Peker, H. (1999). Weathering durability of CCB-impregnated wood for clear varnish coatings. Journal of Wood Science, 45(6), 502-514. http://dx.doi.org/10.1007/ BF00538961.

8. Kamdem, D. P., Pizzi, A., \& Jermannaud, A. (2002). Durability of heat-treated wood. Holz als Roh-und Werkstoff, 60(1), 1-6. http://dx.doi.org/10.1007/s00107-001-0261-1.

9. Lebow, S. T. (2004). Alternatives to Chromated Copper Arsenate (CCA) for residential construction. In Environmental Impacts of Preservative-Treated Wood Conference (pp. 156-168). Orlando, FL, USA: The Florida Center for Environmental Solutions.

10. Barceloux, D. G., \& Barceloux, D. (1999). Chromium. Journal of Toxicology. Clinical Toxicology, 37(2), 173-194. http:// dx.doi.org/10.1081/CLT-100102418. PMid:10382554.

11. Zhang, J., Kamdem, D. P., \& Temiz, A. (2009). Weathering of copper-amine treated wood. Applied Surface Science, 256(3), 842-846. http://dx.doi.org/10.1016/j.apsusc.2009.08.071.

12. Altay, C., Baysal, E., Toker, H., Türkoğlu, T., Küçüktüvek, M., Gündüz, A., \& Peker, H. (2020). Effects of natural weathering on surface characteristics of Scots pine impregnated with wolmanit CX-8 and varnished. Wood Research, 65(1), 87-100. http://dx.doi.org/10.37763/wr.1336-4561/65.1.087100.

13. American Society for Testing and Materials-ASTM. (2007). ASTM 1413-07e1: Standard Test Method For Wood Preservatives By Laboratory Soil-Block Cultures. West Conshohocken!, PA, USA: ASTM International.

14. American Society for Testing and Materials - ASTM. (2017). ASTM D3023- 98: Standard practice for determination of resistance of factory-applied coatings on wood products to stains and reagents. West Conshohocken!, PA, USA: ASTM International.

15. American Society for Testing and Materials-ASTM. (2018). ASTM D523-14: Standard test method for specular gloss. West Conshohocken!, PA, USA: ASTM International.

16. American Society for Testing and Materials - ASTM. (1964). ASTM D1536-58 T: Tentative method of test color difference using the colormaster differential colourimeter. West Conshohocken", PA, USA: ASTM International.

17. American Society for Testing and Materials-ASTM. (1970). ASTM D358-55: Standard specification for wood to be used panels in weathering tests of paints and varnishes. West Conshohocken!', PA, USA: ASTM International.

18. Baysal, E., Dizman Tomak, E., Ozbey, M., \& Altin, E. (2014). Surface properties of impregnated and varnished Scots pine wood after accelerated weathering. Coloration Technology, 130(2), 140-146. http://dx.doi.org/10.1111/cote.12070. 
19. Toker, H., Baysal, E., \& Kesik, H. I. (2009). Surface characteristics of wood pre-impregnated with borates before varnish coating. Forest Products Journal, 59(7-8), 43-46.

20. Türkoğlu, T., Baysal, E., Kureli, I., Toker, H., \& Ergün, M. E. (2015). The effects of natural weathering on hardness and gloss of impregnated and varnished Scots pine and oriental beech. Wood Research, 60(5), 833-844.

21. Pori, P., Vilčnik, A., Petrič, M., Sever Škapin, A., Mihelčič, M., Šurca Vuk, A., Novak, U., \& Orel, B. (2016). Structural studies of $\mathrm{TiO}_{2}$ /wood coatings prepared by hydrothermal deposition of rutile particles from $\mathrm{TiCl}_{4}$ aqueous solutions on spruce (Picea abies) Wood. Applied Surface Science, 372, 125-138. http://dx.doi.org/10.1016/j.apsusc.2016.03.065.

22. Gündüz, A., Baysal, E., Türkoğlu, T., Küçüktüvek, M., Altay, C., Peker, H., \& Toker, H. (2019). Accelerated weathering performance of Scots pine preimpregnated with copper based chemicals before varnish coating. Part II: coated with water based varnish. Wood Research, 64(6), 987-998. Retrieved in 2020, November 17, from http://www.woodresearch.sk/ wr/201906/06.pdf

23. Gündüz, A., Baysal, E., Türkoğlu, T., Altay, C., Küçüktüvek, M., Toker, H., \& Peker, H. (2020). Accelerated weathering performance of Scots pine preimpregnated with copper based chemicals before varnish coating. Part: I coated with cellulosic and polyurethane varnishes. Coloration Technology, 136(1), 34-44. http://dx.doi.org/10.1111/cote. 12435 .
24. Baysal, E., Degirmentepe, S., Toker, H., \& Türkoğlu, T. (2014). Some mechanical and physical properties of AD-KD 5 impregnated and thermally modified Scots pine wood. Wood Research, 59(2), 283-296. Retrieved in 2020, November 17, from http://www.woodresearch.sk/wr/201402/07.pdf

25. Baysal, E. (2012). Surface characteristics of CCA treated Scots pine after accelerated weathering. Wood Research, 57(3), 375-382. Retrieved in 2020, November 17 , from http://www. woodresearch.sk/wr/201203/04.pdf

26. Feist, W., \& Hon, D. N.-S. (1984). Chemistry of weathering and protection. In R. Rowell (Eds.), The chemistry of solid wood (Chap. 11, pp. 401-451). USA: American Chemical Society. http://dx.doi.org/10.1021/ba-1984-0207.ch011.

27. Temiz, A., Yildiz, U. C., Aydin, I., Eikenes, M., Alfredsen, G., \& Colakoglu, G. (2005). Surface roughness and color characteristics of wood treated with preservatives after accelerated weathering test. Applied Surface Science, 250(14), 35-42. http://dx.doi.org/10.1016/j.apsusc.2004.12.019.

28. Ghosh, S. C., Militz, H., \& Mai, C. (2009). Natural weathering of Scots pine (Pinus sylvestris L.) boards modified with functionalised commercial silicone emulsions. BioResources, 4, 659-673. http://dx.doi.org/10.15376/BIORES.4.2.659-673.

Received: Nov. 17, 2020

Revised: Feb. 08, 2021

Accepted: Feb. 09, 2021 